\title{
The requirement of valine for gilts in the initial phase is not influenced by moderate levels of leucine
}

\author{
Laura Marcela Diaz Huepa ${ }^{1 *}$, Leandro Dalcin Castilha', Silvia Letícia Ferreira ${ }^{1}$, Alessandra \\ Nardina Trícia Rigo Monteiro', Alcides Emanuel Rodrigues da Costa ${ }^{1}$, Jesus Alejandro Botero \\ Giraldo', Antonio Claudio Furlan², Paulo Cesar Pozza²
}

\footnotetext{
1 Universidade Estadual de Maringá, Programa de Pós-graduação em Zootecnia, Maringá, PR, Brasil.

${ }^{2}$ Universidade Estadual de Maringá, Departamento em Zootecnia, Maringá, PR, Brasil.
}

\begin{abstract}
The objective of this study was to evaluate the standardized ileal digestible (SID) valine and SID leucine levels on performance, backfat thickness, longissimus dorsi depth, and biochemical blood parameters of starting gilts. A total of 72 gilts, with initial weight of $15.16 \pm 1.15 \mathrm{~kg}$, were distributed in a randomized block design in a $2 \times 4$ factorial scheme, comprised of two SID leucine levels (1.20 and 1.77\%) and four SID valine levels $(0.58,0.73,0.88$, and $1.03 \%)$, with nine replicates and one animal per experimental unit. No interactions were observed for growth performance parameters. Final weight and average daily gain presented linear and quadratic effects. Setting data to the quadratic model associated with the Linear Response Plateau model, the optimal level of SID valine for average daily gain was achieved at $0.703 \%$. A quadratic effect was also observed for average daily feed intake (ADFI), estimating the highest ADFI at $0.822 \%$ of SID valine. No branched chain amino acid (BCAA) effects were observed for backfat thickness, longissimus dorsi depth, and lean meat percentage. The interaction between levels of BCAA showed that the highest SID leucine levels (1.77\%) provided a high plasma urea concentration only at low SID valine levels $(0.58$ and $0.73 \%)$. The SID valine requirement of starting gilts for a maximum average daily gain is achieved at $0.703 \%$, corresponding to $9.72 \mathrm{~g} \mathrm{day}^{-1}$, and is not affected by SID leucine levels currently used in conventional diets.
\end{abstract}

Key Words: antagonism, blood parameters, growth performance

\section{Introduction}

Essential amino acids (EAA) may be included in diets to maintain the physiological functions of body cells and tissues (Wu, 2014). The branched chain amino acids (BCAA) are included in this class, represented by leucine, isoleucine, and valine. The dietary requirements of BCAA for pigs have been studied over time (Gaines et al., 2011; Gloaguen et al., 2012; Lohman et al., 2012; Garcia et al., 2015; Nørgaard et al., 2015; Soumeh et al., 2015), providing the need about its requirements. According to Rostagno et al. (2011), the requirement for starting gilts is $1.081,0.595$, and $0.746 \%$ of leucine, isoleucine, and valine, respectively.

Received: May 4, 2017

Accepted: October 17, 2017

*Corresponding author: lauramvz28@yahoo.com.co

Copyright () 2018 Sociedade Brasileira de Zootecnia. This is an Open Access article distributed under the terms of the Creative Commons Attribution License (http://creativecommons.org/licenses/by/4.0/), which permits unrestricted use, distribution, and reproduction in any medium, provided the original work is properly cited.
Valine has been reported as the fifth limiting amino acid in pig diets based on corn and soybean meal (Gaines et al., 2011), demonstrating the importance of meeting its requirement by supplementing $\mathrm{L}$-valine in the diet.

Leucine has been the most studied BCAA in different animal species and is characterized by important effects on protein stimulation (Gaines et al., 2011; Gloaguen et al., 2012; Columbus et al., 2015; Wessels et al. 2016), but standardized ileal digestible (SID) leucine concentration found in corn and soybean meal is higher compared with SID valine concentrations (Rostagno et al., 2011) and the requirement of animals is easily met; therefore, it becomes difficult to create severe disability (Franco, 2011).

In this sense, excess leucine may adversely affect the viability of other BCAA and, consequently, reduce the growth performance of animals (Morales et al., 2016). Productive parameters such as average daily feed intake (ADFI), average daily gain (ADG), and feed conversion ratio (FCR) are affected by $\mathrm{BCAA}$, and, according to Langer and Fuller (2000), leucine excess increases the oxidation of isoleucine and valine. 
The BCAA requirements for each production phase in pigs and its imbalance in conventional diets needs to be studied. The objective of this study was to evaluate the effects of moderate SID leucine levels on SID valine requirement for starting gilts $(15-30 \mathrm{~kg})$.

\section{Material and Methods}

Research on animals was conducted according to the institution committee on animal use (case no. 8538100616), in Maringá (latitude: $23^{\circ} 25^{\prime} \mathrm{S}$, longitude: $51^{\circ} 57^{\prime} \mathrm{W}$, and altitude of $596 \mathrm{~m}$ ), located in the northwest of the Paraná, Brazil, with subtropical and tropical climate.
Seventy-two gilts (Landrace $\times$ Large White $\times$ Pietrain), averaging $15.16 \pm 1.15 \mathrm{~kg}$ of initial weight, were distributed in a randomized block design in a $2 \times 4$ factorial scheme, with nine replicates and one gilt per experimental unit, consisting of two levels of SID leucine (1.20 and 1.77\%) and four levels of SID valine $(0.58,0.73,0.88$, and $1.03 \%)$.

The experimental diets were formulated with corn, soybean meal, minerals, vitamins, amino acids, and additives (Table 1). The crude protein (CP) content was reduced in relation to that suggested by Rostagno et al. (2011). L-leucine and L-valine were added to diets at the expense of sand. Glutamic acid was used to maintain the same nitrogen content in the experimental diets.

Table 1 - Chemical and energetic composition of diets containing different levels of SID leucine and SID valine for gilts from 15 to $30 \mathrm{~kg}$ of live weight

\begin{tabular}{|c|c|c|c|c|c|c|c|c|}
\hline \multirow{2}{*}{$\begin{array}{l}\text { SID leucine }(\%) \\
\text { SID valine }(\%)\end{array}$} & \multicolumn{4}{|c|}{1.20} & \multicolumn{4}{|c|}{1.77} \\
\hline & 0.58 & 0.73 & 0.88 & 1.03 & 0.58 & 0.73 & 0.88 & 1.03 \\
\hline \multicolumn{9}{|l|}{ Ingredient ( $\mathrm{g} \mathrm{kg}^{-1}$ as fed) } \\
\hline Corn & 760.21 & 760.21 & 760.21 & 760.21 & 760.21 & 760.21 & 760.21 & 760.21 \\
\hline Soybean meal & 179.00 & 179.00 & 179.00 & 179.00 & 179.00 & 179.00 & 179.00 & 179.00 \\
\hline Dicalcium phosphate & 16.06 & 16.06 & 16.06 & 16.06 & 16.06 & 16.06 & 16.06 & 16.06 \\
\hline Limestone & 8.33 & 8.33 & 8.33 & 8.33 & 8.33 & 8.33 & 8.33 & 8.33 \\
\hline Salt & 4.56 & 4.56 & 4.56 & 4.56 & 4.56 & 4.56 & 4.56 & 4.56 \\
\hline Soybean oil & 4.98 & 4.93 & 4.89 & 4.84 & 3.09 & 2.32 & 1.56 & 0.79 \\
\hline Glutamic acid & 7.40 & 5.22 & 3.05 & 0.87 & 1.37 & 0.91 & 0.46 & 0.00 \\
\hline L-lysine $\mathrm{HCl}$ & 6.45 & 6.45 & 6.45 & 6.45 & 6.45 & 6.45 & 6.45 & 6.45 \\
\hline L-threonine & 2.45 & 2.45 & 2.45 & 2.45 & 2.45 & 2.45 & 2.45 & 2.45 \\
\hline DL-methionine & 1.84 & 1.84 & 1.84 & 1.84 & 1.84 & 1.84 & 1.84 & 1.84 \\
\hline L-tryptophan & 0.64 & 0.64 & 0.64 & 0.64 & 0.64 & 0.64 & 0.64 & 0.64 \\
\hline L-valine & 0.05 & 1.62 & 3.20 & 4.77 & 0.05 & 1.62 & 3.20 & 4.77 \\
\hline L-isoleucine & 0.96 & 0.96 & 0.96 & 0.96 & 0.96 & 0.96 & 0.96 & 0.96 \\
\hline L-leucine & 0.00 & 0.00 & 0.00 & 0.00 & 5.92 & 5.92 & 5.92 & 5.92 \\
\hline Vitamin + mineral supplement ${ }^{1}$ & 5.00 & 5.00 & 5.00 & 5.00 & 5.00 & 5.00 & 5.00 & 5.00 \\
\hline Sand & 2.02 & 2.67 & 3.32 & 3.97 & 4.01 & 3.67 & 3.32 & 2.97 \\
\hline Antibiotic $^{2}$ & 0.05 & 0.05 & 0.05 & 0.05 & 0.05 & 0.05 & 0.05 & 0.05 \\
\hline Total & 1000 & 1000 & 1000 & 1000 & 1000 & 1000 & 1000 & 1000 \\
\hline \multicolumn{9}{|l|}{ Calculated composition } \\
\hline Metabolizable energy $\left(\mathrm{MJ} \mathrm{kg}^{-1}\right)$ & 13.51 & 13.51 & 13.51 & 13.51 & 13.51 & 13.51 & 13.51 & 13.51 \\
\hline Total nitrogen $(\%)$ & 2.44 & 2.44 & 2.44 & 2.44 & 2.45 & 2.46 & 2.48 & 2.49 \\
\hline Calcium ( $\mathrm{g} \mathrm{kg}^{-1}$ as fed) & 0.774 & 0.774 & 0.774 & 0.774 & 0.773 & 0.774 & 0.774 & 0.774 \\
\hline Available phosphorus ( $\mathrm{g} \mathrm{kg}^{-1}$ as fed) & 3.82 & 3.82 & 3.82 & 3.82 & 3.82 & 3.82 & 3.82 & 3.82 \\
\hline Sodium $\left(\mathrm{g} \mathrm{kg}^{-1}\right.$ as fed $)$ & 2.00 & 2.00 & 2.00 & 2.00 & 2.00 & 2.00 & 2.00 & 2.00 \\
\hline Potassium ( $\mathrm{g} \mathrm{kg}^{-1}$ as fed $)$ & 5.50 & 5.50 & 5.50 & 5.50 & 5.50 & 5.50 & 5.50 & 5.50 \\
\hline Cloride $\left(\mathrm{g} \mathrm{kg}^{-1}\right.$ as fed $)$ & 4.51 & 4.51 & 4.51 & 4.51 & 4.51 & 4.51 & 4.51 & 4.51 \\
\hline SID lysine $\left(\mathrm{g} \mathrm{kg}^{-1}\right.$ as fed $)$ & 10.81 & 10.81 & 10.81 & 10.81 & 10.81 & 10.81 & 10.81 & 10.81 \\
\hline SID methionine + cystine $\left(\mathrm{g} \mathrm{kg}^{-1}\right.$ as fed $)$ & 6.05 & 6.05 & 6.05 & 6.05 & 6.05 & 6.05 & 6.05 & 6.05 \\
\hline SID threonine $\left(\mathrm{g} \mathrm{kg}^{-1}\right.$ as fed $)$ & 6.81 & 6.81 & 6.81 & 6.81 & 6.81 & 6.81 & 6.81 & 6.81 \\
\hline SID tryptophan ( $\mathrm{g} \mathrm{kg}^{-1}$ as fed) & 1.95 & 1.95 & 1.95 & 1.95 & 1.95 & 1.95 & 1.95 & 1.95 \\
\hline SID $\operatorname{arginine}\left(\mathrm{g} \mathrm{kg}^{-1}\right.$ as fed $)$ & 8.13 & 8.13 & 8.13 & 8.13 & 8.13 & 8.13 & 8.13 & 8.13 \\
\hline SID valine $\left(\mathrm{g} \mathrm{kg}^{-1}\right.$ as fed $)$ & 5.80 & 7.30 & 8.80 & 10.30 & 5.80 & 7.30 & 8.80 & 10.30 \\
\hline SID leucine ( $\mathrm{g} \mathrm{kg}^{-1}$ as fed $)$ & 12.60 & 12.60 & 12.60 & 12.60 & 17.70 & 17.70 & 17.70 & 17.70 \\
\hline SID isoleucine $\left(\mathrm{g} \mathrm{kg}^{-1}\right.$ as fed $)$ & 5.95 & 5.95 & 5.95 & 5.95 & 5.95 & 5.95 & 5.95 & 5.95 \\
\hline SID methionine ( $\mathrm{g} \mathrm{kg}^{-1}$ as fed) & 3.84 & 3.84 & 3.84 & 3.84 & 3.84 & 3.84 & 3.84 & 3.84 \\
\hline SID phenylalanine + tyrosine $\left(\mathrm{g} \mathrm{kg}^{-1}\right.$ as fed $)$ & 10.62 & 10.62 & 10.62 & 10.62 & 10.62 & 10.62 & 10.62 & 10.62 \\
\hline SID phenylalanine $\left(\mathrm{g} \mathrm{kg}^{-1}\right.$ as fed $)$ & 6.31 & 6.31 & 6.31 & 6.31 & 6.31 & 6.31 & 6.31 & 6.31 \\
\hline
\end{tabular}

SID - standardized ileal digestible.

${ }^{1}$ Provide per kilogram of diet (nutrition levels $\mathrm{kg}^{-1}$ of diet): vitamin A, 10,000 IU; vitamin D3, 2,000 IU; vitamin E, 20 IU; vitamin B1, 1.96 mg; vitamin B2, 4,265 mg; vitamin B6, $1.98 \mathrm{mg}$; vitamin B12, 26,665 mcg; vitamin K3, 2,425 mg; calcium pantothenate, $15.83 \mathrm{mg}$; niacin, $42,665 \mathrm{mg}$; folic acid, $0.53 \mathrm{mg}$; biotin, $0.13 \mathrm{mg}$; BHT, $10 \mathrm{mg}$; Zn, $0.1 \mathrm{~g}$; Fe, 0.075 g; Mn, $0.052 \mathrm{mg}$; Cu, $12 \mathrm{mg}$; I, $0.825 \mathrm{mg}$; Co, $0.135 \mathrm{mg}$; Se, $0.3 \mathrm{mg}$; vehicle q.s.p., 5 g.

${ }^{2}$ Leucomag (Ceva Animal Health, Paulínia, Brazil). 
The amino acid compositions of corn and soybean meal used in the diet formulation were obtained through near-infrared spectroscopy (NIRS), and the coefficients of standardized digestibility of amino acids proposed by Rostagno et al. (2011) were applied to the analyzed data.

The animals were housed in a nursery with suspended pens $\left(1.32 \mathrm{~m}^{2}\right)$ and partly leaked floor, equipped with feeders, located in the front of the pen, and a nipple-type drinker, in the backside. Each replicate had a length of approximately 20 days.

Animals were weighted at the beginning and at the end of the experiment, and the diets were weighted whenever provided to the animals for the determination of ADFI, ADG, and FCR.

At the end of the experiment, the animals were subjected to the evaluation of backfat thickness (BT) and longissimus dorsi depth (LD) by using an ultrasound equipment (Aloka ${ }^{\circledR}$ SSD $500 \mathrm{Vet}$ ) coupled to a probe of $7.5 \mathrm{~cm}$ and 3.5 MHz. The P2 site, located at the last rib of the chest, was determined at $6 \mathrm{~cm}$ from the midline, where the site was cleaned and the images were registered. Afterwards, the measurements of BT and LD were performed by using the Image Pro Plus ${ }^{\circledR}$ software.

The lean meat percentage (LMP) was predicted by using an equation parameter as follows:

$\mathrm{Y}=60.69798-0.89211 \mathrm{~S}+0.10560 \mathrm{M}$ (Vítek et al., 2008), in which $\mathrm{Y}=$ estimated percentage of lean meat, $\mathrm{S}=$ backfat thickness $(\mathrm{cm})$, and $\mathrm{M}=$ depth of the muscle at the measurement point.

After a six-hour fast, cranial vena cava blood samples were collected and stored in tubes containing EDTA anticoagulant (Cai et al., 1994) to determine urea, total protein, creatinine, alanine aminotransferase, and aspartate aminotransferase in the blood plasma. For glucose determination, the blood samples were collected into glass tubes containing sodium fluoride.

Blood samples were centrifuged at 3,000 RPM during 15 min to obtain blood plasma, and samples used for glucose determination were centrifuged during $30 \mathrm{~min}$. Then, $3 \mathrm{~mL}$ of blood plasma were transferred to Eppendorf ${ }^{\circledR}$ type tubes.

The biochemical analyses were performed by using enzymatic colorimetric Kits $\left(\right.$ Laborclin $\left.^{\circledR}\right)$, following the operational procedures described for each one. The concentration of the blood biochemical components were determined by absorbance reading (BIOPLUS ${ }^{\circledR} 2000$ Spectrophotometer).

To determine hematocrit concentration, the blood was transferred to capillary microtubes and centrifuged at 12,000 RPM for 5 min.
Data regarding performance, BT, LD, LMP, and blood parameters were subjected to analysis of variance. The $\mathrm{F}$ test was applied to the means obtained for SID leucine levels. The degrees of freedom related to SID valine levels were deployed in orthogonal polynomials for regression fitting. The initial weight was used as a covariate for the performance parameters. Data were also adjusted by the quadratic model associated and LRP model. Statistical analysis were performed by the Statistical and Genetic Analysis System - SAEG (Universidade Federal de Viçosa, 2009).

\section{Results}

No interactions $(\mathrm{P}>0.05)$ were observed between SID leucine $(1.20$ and $1.77 \%)$ and SID valine $(0.58,0.73,0.88$, and $1.03 \%$ ) on growth performance (Table 2). Thus, the studied SID leucine levels did not affect the SID valine requirements, even at the highest leucine level (1.77\%).

Quadratic effects were observed (Table 2) for FW $(\mathrm{P}=0.0034)$, ADG $(\mathrm{P}=0.0003)$, and ADFI $(\mathrm{P}=0.0007)$ according to increased SID valine levels. The quadratic equation associated with the LRP model estimated the optimum SID valine at $0.703 \%$ for ADG (Figure 1). The quadratic equation model estimated the highest ADFI at the level of $0.825 \%$ of SID valine $\left(1.421 \mathrm{~kg}\right.$ of feed day $\left.{ }^{-1}\right)$.

Plasma levels of total protein, creatinine, alanine aminotransferase, aspartate aminotransferase, and hematocrit were not affected $(\mathrm{P}>0.05)$ by SID leucine and SID valine. However, effect of SID leucine levels (1.20 and 1.77\%) for glucose means was observed $(\mathrm{P}=0.0013)$ (Table 3 ).

An interaction $(\mathrm{P}=0.0477)$ between SID leucine and SID valine was observed for plasma urea concentration (Table 3), in which an increased plasma urea concentration was observed when gilts received diets with the highest SID leucine $(1.77 \%)$ only at 0.58 and 0.73 of SID valine (Table 4).

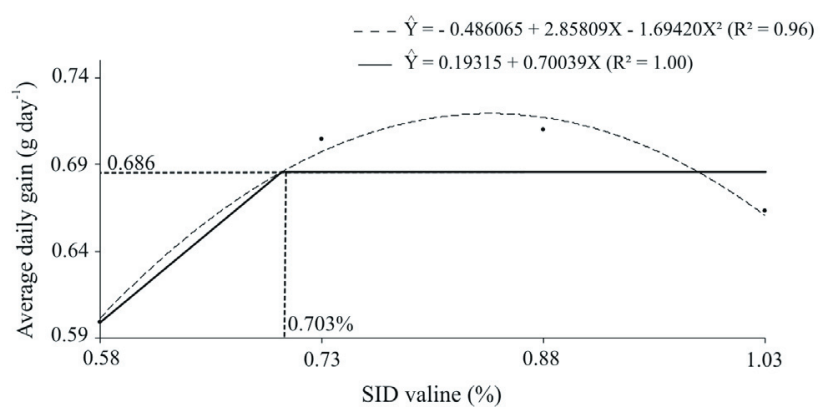

SID - standardized ileal digestible.

Figure 1 - Average daily gain $\left(\mathrm{g} \mathrm{day}^{-1}\right)$ as a function of SID valine levels in diets of starting gilts. 
Table 2 - Performance, longissimus dorsi depth (LD), backfat thickness (BT), and lean meat percentage (LMP) of gilts fed low crude protein diets with different levels of SID leucine and SID valine

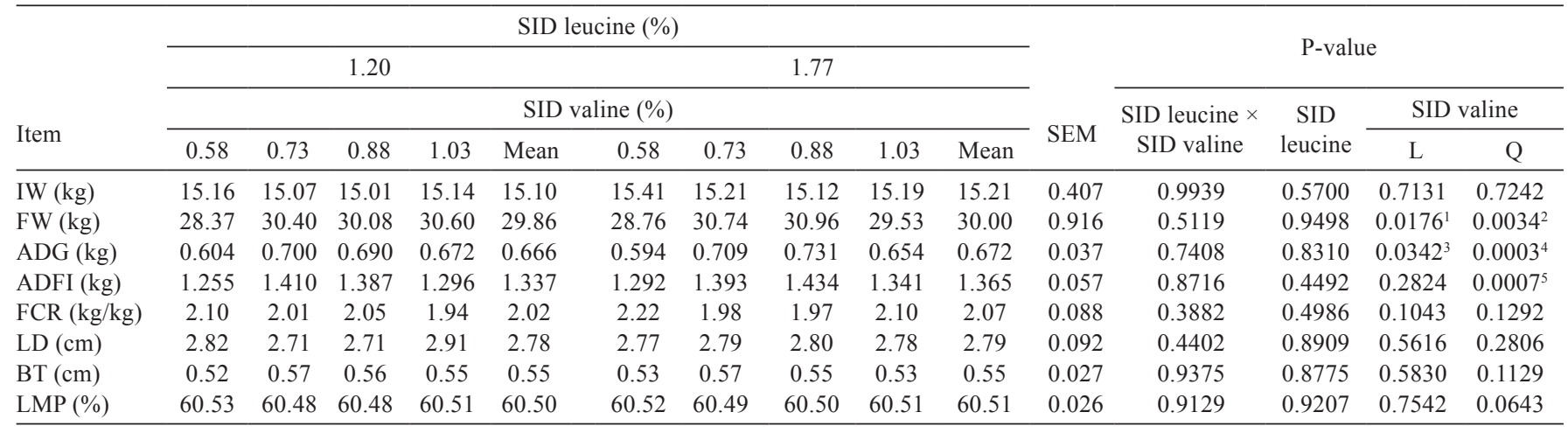

IW - initial weight; FW - final weight; ADG - average daily gain; ADFI - average daily feed intake; FCR - feed conversion ratio; SEM - standard error of mean; L - linear; $\mathrm{Q}$ - quadratic.

${ }^{1} \mathrm{Y}=20.82632+13.34547 \mathrm{X}\left(\mathrm{R}^{2}=1.00\right)$.

${ }^{2} \mathrm{Y}=10.6285+46.9032 \mathrm{X}-27.2980 \mathrm{X}^{2}\left(\mathrm{R}^{2}=0.78\right)$

${ }^{3} \mathrm{Y}=0.1931538+0.70039 \mathrm{X}\left(\mathrm{R}^{2}=1.00\right)$.

${ }^{4} \mathrm{Y}=-0.486065+2.85809 \mathrm{X}-1.69420 \mathrm{X}^{2}\left(\mathrm{R}^{2}=0.96\right)$

${ }^{5} \mathrm{Y}=-0.239161+4.02503 \mathrm{X}-2.44022 \mathrm{X}^{2}\left(\mathrm{R}^{2}=0.94\right)$

Table 3 - Plasma levels of glucose, urea, total proteins, creatinine, alanine aminotransferase (ALT), aspartate aminotransferase (AST), and hematocrit of gilts fed low crude protein diets with different levels of SID leucine and SID valine

\begin{tabular}{|c|c|c|c|c|c|c|c|c|c|c|c|c|c|c|c|}
\hline \multirow{3}{*}{ Item } & \multicolumn{10}{|c|}{ SID leucine (\%) } & \multirow{2}{*}{\multicolumn{5}{|c|}{ P-value }} \\
\hline & \multicolumn{5}{|c|}{1.20} & \multicolumn{5}{|c|}{1.77} & & & & & \\
\hline & & & & & SID vali & e $(\%)$ & & & & & SEM & $\begin{array}{l}\text { SID leucine } \times \\
\text { SID valine }\end{array}$ & $\begin{array}{l}\text { SID } \\
\text { leucine }\end{array}$ & \multicolumn{2}{|c|}{ SID valine } \\
\hline Glucose $\left(\mathrm{mg} \mathrm{dL}^{-1}\right)$ & 82.33 & 78.31 & 71.50 & 80.83 & $78.24 \mathrm{a}$ & 85.17 & 82.58 & 89.25 & 87.08 & $86.02 \mathrm{~b}$ & 3.385 & 0.0941 & 0.0013 & 0.9566 & 0.1341 \\
\hline Urea $\left(\mathrm{mg} \mathrm{dL}^{-1}\right)$ & 11.86 & 10.00 & 11.88 & 12.83 & 11.64 & 15.03 & 12.86 & 13.45 & 11.50 & 13.21 & 0.928 & 0.0477 & 0.0132 & 0.3437 & 0.2178 \\
\hline Total proteins $\left(\mathrm{mg} \mathrm{dL}^{-1}\right)$ & 5.12 & 5.17 & 5.40 & 5.37 & 5.26 & 4.90 & 5.34 & 5.40 & 5.22 & 5.22 & 0.186 & 0.6755 & 0.6867 & 0.0744 & 0.1523 \\
\hline $\operatorname{AST}\left(\mathrm{U} \mathrm{L}^{-1}\right)$ & 53.58 & 51.17 & 39.83 & 48.75 & 48.33 & 39.80 & 42.14 & 42.00 & 45.43 & 42.34 & 4.994 & 0.4487 & 0.1077 & 0.7814 & 0.3993 \\
\hline Hematocrit $(\%)$ & 34.83 & 38.34 & 35.58 & 34.55 & 35.83 & 30.75 & 33.90 & 32.60 & 35.25 & 33.13 & 1.508 & 0.2314 & 0.0766 & 0.3247 & 0.1981 \\
\hline
\end{tabular}

SID - standardized ileal digestible; SEM - standard error of mean; L - linear; Q - quadratic.

Means followed by different letters in the line differ from one another by the $\mathrm{F}$ test.

Table 4 - Deployment of SID leucine vs SID valine levels for plasma urea of gilts

\begin{tabular}{lcccccc}
\hline \multirow{2}{*}{ Item } & \multirow{2}{*}{ SID } & \multicolumn{5}{c}{ SID valine (\%) } \\
\cline { 3 - 6 } & leucine (\%) & 0.58 & 0.73 & 0.88 & 1.03 & \\
\hline Urea $\left(\mathrm{mg} \mathrm{dL}^{-1}\right)$ & 1.20 & $11.86 \mathrm{a}$ & $10.00 \mathrm{a}$ & $11.88 \mathrm{a}$ & $12.83 \mathrm{a}$ & 11.64 \\
& 1.77 & $15.03 \mathrm{~b}$ & $12.86 \mathrm{~b}$ & $13.45 \mathrm{a}$ & $11.50 \mathrm{a}$ & 13.21 \\
Mean & & 13.44 & 11.43 & 12.66 & 12.16 & 12.42 \\
\hline
\end{tabular}

SID - standardized ileal digestible; SEM - standard error of mean.

Means followed by the same lowercase letters in the columns do not differ significantly by the $\mathrm{F}$ test at the $5 \%$ level of significance.

\section{Discussion}

No interactions were observed (Table 2) between the studied BCAA, demonstrating that SID leucine levels did not affect SID valine requirement, even at the highest leucine level (1.77\%) in the diets.
Thus, there is no L-leucine inclusion in commercial pig diets because, unlike valine, a high concentration of leucine is found in feedstuffs commonly used in pig diets, indicating that SID leucine, even at levels above those normally suggested as a requirement (Rostagno et al., 2011; NRC, 2012) and up to the high level studied (1.77\%) do not affect SID valine requirements of starting gilts.

The results obtained are similar to those reported by Gloaguen et al. (2012), who studied the valine requirement of 10 to $20-\mathrm{kg}$ piglets (a diet without addition of L-valine and a diet with $0.18 \%$ of L-valine) and reported that this requirement does not seem to depend on leucine intake.

It is reasonable to remember that the high SID leucine level studied $(1.77 \%)$ is near, or a little higher, compared with that observed in commercial diets for starting pigs, showing that SID valine requirements is not affected by SID leucine levels currently used in commercial diets for 
starting pigs. However, leucine excess in valine-deficient diets do not affect the valine utilization to the same extent as isoleucine-deficient diets (Pelletier et al., 1991; Langer and Fuller, 2000). This is due to the competition of branched-chain ketoacids, since $\alpha$-keto- $\beta$-methylvalerate and $\alpha$-ketoisovalerate have similar values of $\mathrm{K}_{\mathrm{m}}$ (Michaelis-Menten constant), competing with substrates for branched-chain ketoacid dehydrogenase (Boyer and Odessey, 1990).

Valine deficiency in pig diets (less than $0.74 \%$ of SID valine) causes a reduction in growth performance. Thus, the first response of the animal to this imbalance is a decreased feed intake, which causes a reduction in weight gain (Gloaguen et al., 2012). This response was observed in the present study, since increasing SID valine levels $(0.58$, $0.73,0.88$, and $1.03 \%$ ) showed improvements in ADG (Figure 1) up to $0.703 \%$ of SID valine.

The results obtained by Gloaguen et al. (2012) showed that feed intake of piglets fed a valine-deficient diet rapidly decreased. In the present study, a low ADFI was also observed in animals fed diets deficient in SID valine (Table 2); however, the daily feed intake was higher than that suggested by Rostagno et al. (2011), namely $1.2 \mathrm{~kg} \mathrm{day}^{-1}$. This effect is probably mediated by a reduction in protein retention, as AA deficiency in diets results in a reduction in nitrogen retention. Thus, one of the first responses to this deficiency by the animal is the reduction in feed intake, resulting in a reduced growth rate (Gloaguen et al., 2012), corroborating the ADG results (Figure 1).

Evaluating L-valine inclusion in diets for 28-day-old piglets, Nørgaard and Fernández (2009) reported that the optimal SID valine was $0.72 \%$, and its supplementation provided a better ADG, also corroborating the results obtained in the present study for the same parameter.

The optimal SID valine level obtained for ADG (Figure 1) is lower than those reported by Mavromichalis et al. (2001), who observed improvements in piglet weight gain (10 to $20 \mathrm{~kg}$ ) by adding $0.50 \% \mathrm{~L}$-valine in the diet, with an optimal SID valine level achieved at 0.75 and $0.80 \%$. However, Rostagno et al. (2011) suggested higher SID valine requirement $(0.746 \%)$ than the obtained in this study $(0.704 \%)$. These differences may be partially related to ADFI because Rostagno et al. (2011) proposed a lower ADFI than the obtained (Table 2); however, these differences, expressed as percentage in the diet and ADFI, equalizes the daily requirement of SID valine.

This variation in SID valine requirements is also observed in other studies (Nørgaard and Fernández, 2009;
Gloaguen et al., 2012; Soumeh et al., 2015), but consistently showed improvement in growth performance parameters (ADG and FW) as observed in the present study.

The L-valine supplementation in low (17\%) and high (20\%) CP diets for weaned piglets was studied by Lordelo et al. (2008), observing improvements in ADFI $(0.955 \mathrm{~kg})$ and ADG for low CP diets containing $0.15 \% \mathrm{~L}$-valine. In addition, valine supplementation reduced the excretion of total nitrogen into the environment, demonstrating a better use of the ingested amino acid (AA).

Wiltafsky et al. (2010) observed no quadratic and/or LRP response obtained for ADG (Figure 1), reporting that ADG and FW linearly reduced, providing a $0.60 \%$ SID valine:lysine ratio for a better FW and ADG. This ratio is lower than that obtained in the present study $(0.65 \%)$, which is an intermediate ratio compared with that suggested by Rostagno et al. (2011) and NRC (2012).

The highest SID leucine level (1.77\%) showed a higher glucose concentration (86.02 $\mathrm{mg} \mathrm{dL}^{-1}$ ) (Table 3 ). According to Kawaguchi et al. (2011), BCAA affect the glucose metabolism, mainly leucine, because its excess stimulates the increased uptake of glucose by the intracellular transporter GLUT4 (Arakawa et al., 2011). Leucine excess increases valine and isoleucine catabolism in pigs by the same pathways as poultry, rats, and humans, increasing nitrogen excretion (Langer and Fuller, 2000). As urea is the main product of protein catabolism, pigs fed excess AA in the diet are supposed to show a high plasma urea concentration because the AA not used for the synthesis of new AA, or nitrogen products, have their amino groups excreted as urea (Nelson and Cox, 2011).

The low level of SID leucine (1.20\%) associated with 0.58 and $0.73 \%$ of SID valine provided a decreased plasma urea concentration (Table 4), since an interaction was observed between the BCAA. The AA plasma concentration is a dynamic process, and leucine excess in the diet is related to a high valine and isoleucine degradation due to the competition for dehydrogenase of the branched-chain $\alpha$-ketoacid (Harris et al., 2001). This response was observed by Gatnau et al. (1995), who attributed the reduction in plasma concentrations of valine and isoleucine to excess leucine and its metabolites in piglet diets. In this sense, plasma urea concentrations may be a good indicator of the amino acid degradation process. According to Reeds et al. (1987), metabolic changes of excess leucine in the diet can be studied by measuring urea synthesis and by leucine turnover, as well as isoleucine and valine (Holecek, 2013).

Evaluating SID valine levels for 15 to $30 \mathrm{~kg}$ barrows, Lohman et al. (2012) observed an increased plasma 
creatinine concentration as SID valine increased in the diet. However, no response $(\mathrm{P}>0.05)$ was observed in the plasma creatinine concentration in the present study (Table 3). According to Motta (2009), creatinine is an indicator of the dietary protein quality passing from the muscle (increase of catabolism) to the plasma, from where it is removed at a constant ratio. This seems to demonstrate that muscle protein degradation was not affected by the SID leucine and SID valine levels evaluated in this study.

\section{Conclusions}

The standard ileal digestible valine requirements for starting gilts improve the average daily gain $(0.703 \%)$ and when is associated with the standard ileal digestible leucine, decrease plasma urea $\left(10.00 \mathrm{mg} \mathrm{dL}^{-1}\right)$.

\section{References}

Arakawa, M.; Masaki, T.; Nishimura, J.; Seike, M. and Yoshimatsu, H. 2011. The effects of branched-chain amino acid granules on the accumulation of tissue triglycerides and uncoupling proteins in diet-induced obese mice. Endocrine Journal 58:161-170.

Boyer, B. and Odessey, R. 1990. Quantitative control analysis of branched-chain 2-oxo acid dehydrogenase complex activity by feedback inhibition. Biochemical Journal 271:523-528.

Cai, Y.; Zimmerman, D. R. and Ewan, R. C. 1994. Diurnal variation in concentrations of plasma urea nitrogen and amino acids in pigs given free access to feed or fed twice daily. The Journal of Nutrition 124:1088-1093.

Columbus, D. A.; Steinhoff-Wagner, J.; Suryawan, A.; Nguyen, H. V.; Hernandez-Garcia, A.; Fiorotto, M. L. and Davis, T. A. 2015. Impact of prolonged leucine supplementation on protein synthesis and lean growth in neonatal pigs. American Journal of PhysiologyEndocrinology and Metabolism 309:E601-E610.

Franco, S. M. 2011. Níveis dietéticos de leucina, de histidina e de fenilalanina + tirosina para frangos de corte na fase inicial. Dissertação (M. Sc.). Universidade Federal de Viçosa, Viçosa, MG.

Gaines, A. M.; Kendall, D. C.; Allee, G. L.; Usry, J. L. and Kerr, B. J. 2011. Estimation of the standardized ileal digestible valine-tolysine ratio in 13- to 32-kilogram pigs. Journal of Animal Science 89:736-742.

Garcia, H.; Morales, A.; Araizal, A.; Htoo, J. K. and Cervantes, M. 2015. Gene expression, serum amino acid levels, and growth performance of pigs fed dietary leucine and lysine at different ratios. Genetics and Molecular Research 14:1589-1601.

Gatnau, R.; Zimmerman, D. R.; Nissen, S. L.; Wannemuehler, M. and Ewan, R. C. 1995. Effects of excess dietary leucine and leucine catabolites on growth and immune responses in weanling pigs. Journal of Animal Science 73:159-165.

Gloaguen, M.; Le Floc'h, N.; Corrent, E.; Primot, Y. and van Milgen, J. 2012. Providing a diet deficient in valine but with excess leucine results in a rapid decrease in feed intake and modifies the postprandial plasma amino acid and $\alpha$-keto acid concentrations in pigs. Journal of Animal Science 90:3135-3142.

Harris, R. A.; Kobayashi, R.; Murakami, T. and Shimomura, Y. 2001. Regulation of branched-chain $\alpha$-keto acid dehydrogenase kinase expression in rat liver. The Journal of Nutrition 131:841-845.
Holecek, M. 2013. Branched-chain amino acids and ammonia metabolism in liver disease: Therapeutic implications. Nutrition 29:1186-1191

Kawaguchi, T.; Izumi, N.; Charlton, M. R. and Sata, M. 2011. Branched-chain amino acids as pharmacological nutrients in chronic liver disease. Hepatology 54:1063-1070.

Langer, S. and Fuller, M. F. 2000. Interactions among the branchedchain amino acids and their effects on methionine utilization in growing pigs: effects on nitrogen retention and amino acid utilization. The British Journal of Nutrition 83:43-48.

Lohman, A. C. Pozza, P. C.; Pozza, M. S. dos S.; Nunes, R. V.; Castilha, L. D.; Possamai, M.; Bruno, L. D. G. and Lazerri, D. B. 2012. Níveis de valina digestível para suínos machos castrados dos 15 aos $30 \mathrm{~kg}$. Archivos de Zootecnia 61:267-278.

Lordelo, M. M.; Gaspar, A. M.; Le Bellego, L. and Freire, J. P. B. 2008. Isoleucine and valine supplementation of a low-protein corn-wheat-soybean meal-based diet for piglets: Growth performance and nitrogen balance. Journal of Animal Science 86:2936-2941.

Mavromichalis, I.; Kerr, B. J.; Parr, T. M.; Albin, D. M.; Gabert, V. M. and Baker, D. H. 2001. Valine requirement of nursery pigs. Journal of Animal Science 79:1223-1229.

Morales, A.; Arcel, N.; Cota, M.; Buenabad, L.; Avelar, E.; Htoo, J. K. and Cervantes, M. 2016. Effect of dietary excess of branchedchain amino acids on performance and serum concentrations of amino acids in growing pigs. Journal of Animal Physiology and Animal Nutrition 100:39-45.

Motta, V. T. 2009. Bioquímica clínica para o laboratório. 5.ed. Medbook, Curitiba.

NRC - National Research Council. 2012. Nutrients requirement of swine. 11th ed. National Academic Press, Washington, DC.

Nelson, D. L. and Cox, M. M. 2011. Princípios de bioquímica de Lehninger. 5.ed. Sarvier, São Paulo.

Nørgaard, J. V. and Fernandéz, J. A. 2009. Isoleucine and valine supplementation of crude protein-reduced diets for pigs aged 5-8 weeks. Animal Feed Science and Technology 154:248-253.

Nørgaard, J. V.; Pedersen, T. F.; Soumeh, E. A.; Blaabjerg, N.; Canibe, N.; Jensen, B. B. and Poulsen, H. D. 2015. Optimum standardized ileal digestible tryptophan to lysine ratio for pigs weighing 7-14 kg. Livestock Science 175:90-95.

Pelletier, V.; Marks, L.; Wagner, D. A.; Hoerr, R. A. and Young, V. R. 1991. Branched-chain amino acid interactions with reference to amino acid requirements in adult men: Valine metabolism at different leucine intakes. The American Journal of Clinical Nutrition 54:395-401.

Reeds, P. J.; Fuller, M. F.; Cadenhead, A. and Hay, S. M. 1987. Urea synthesis and leucine turnover in growing pigs: changes during $2 \mathrm{~d}$ following the addition of carbohydrate or fat to the diet. The British Journal of Nutrition 58:301-311.

Rostagno, H. S.; Albino, L. F. T.; Donzele, J. L.; Gomes, P. C.; Oliveira, R. F.; Lopes, D. C.; Ferreira, A. S.; Barreto, S. L. T. and Euclides, R. F. 2011. Tabelas brasileiras para aves e suínos: composição de alimentos e exigências nutricionais. 3.ed. UFV, Viçosa, MG, Brasil.

Soumeh, E. A.; van Milgen, J.; Sloth, N. M.; Corrent, E.; Poulsen, H. D. and Nørgaard, J. V. 2015. Requirement of standardized ileal digestible valine to lysine ratio for $8-$ to $14-\mathrm{kg}$ pigs. Animal 9:1312-1318.

Vítek, M.; Pulkrábek, J.; Vališ, L.; David, L. and Wolf, J. 2008. Improvement of accuracy in the estimation of lean meat content in pig carcasses. Czech Journal of Animal Science 53:204-211.

Wessels, A. G.; Kluge, H.; Hirche, F.; Kiowski, A.; Schutkowski, A.; Corrent, E.; Bartelt, J.; Konig, B. and Stangl, I. 2016. High leucine 
diets stimulate cerebral branched-chain amino acid degradation and modify serotonin and ketone body concentrations in a pig model. Plos One 11:e0150376. https://doi.org/10.1371/journal.pone.0150376

Wiltafsky, M. K.; Pfaffl, M. W. and Roth, F. X. 2010. The effects of branched-chain amino acid interactions on growth performance, blood metabolites, enzyme kinetics and transcriptomics in weaned pigs. British Journal of Nutrition 103:964-976.

Wu, G. 2014. Dietary requirements of synthesizable amino acids by animals: a paradigm shift in protein nutrition. Journal of Animal Science and Biotechnology 5:34. 